\title{
Studi Implementasi Smart Grid Solar PV System Di Gedung G Universitas Muhammadiyah Jember
}

\author{
M A’an Auliq, Fitriana, Siti Robitoh \\ Program Studi Teknik Elektro, Fakultas Teknik, Universitas Muhammadiyah Jember \\ Jl. Karimata 49 Jember 68121 Jawa Timur Indonesia \\ E-mail: Sitirobito69@gmail.com
}

\begin{abstract}
ABSTRAK
Abstrak - Pemanfaatan energi listrik di Gedung G Universitas Muhammadiyah Jember bersumber dari PLN sebesar 6,6 KVA. Energi listrik yang digunakan untuk mencukupi kebutuhan energi listrik 3 lantai. Penggunaan energi listrik di Gedung G juga memanfaatkan energi tambahan. Teknologi yang digunakan Smart Grid Solar PV System yang bekerja secara hybrid dengan jaringan PLN untuk memenuhi beban. Analisis data dalam studi ini menggunakan metode pengumpulan data berupa daya pada panel surya menggunakan aplikasi perangkat lunak IMEON Manager dengan waktu pengambilan selama 4 minggu dengan waktu 7 jam per hari dengan rentang waktu 10 menit. Estimasi total kebutuhan energi harian Gedung G Universitas Jember sebesar $1980 \mathrm{kWh} /$ hari untuk mengantisipasi penambahan beban maka energi dicadangkan sebesar 30\% dari total energi yang dicadangkan sebesar 594,0 Wh/hari. Sehingga daya yang dibangkitkan dengan area array $678,8 \mathrm{~m}^{2}$ dan 14 jumlah panel surya sebesar $3640 \mathrm{Wp}$.
\end{abstract}

Kata kunci: Smart Grid, Solar PV System, Hybrid, PLN

\section{ABSTRACT}

Abstract - The utilization of electrical energy in G Building, University of Muhammadiyah Jember comes from PLN of 6.6 KVA. Electrical energy is used to meet the needs of 3 floors of electrical energy. The use of electrical energy in G Building also uses additional energy. The technology used by the Smart Grid Solar PV System works in a hybrid manner with the PLN network to meet the load. The data analysis in this study used the data collection method in the form of power on the solar panel using the IMEON Manager software application with a retrieval time of 4 weeks with a time of 7 hours per day with a span of 10 minutes. Estimation of the total daily energy needs of G Building University of Jember of $1980 \mathrm{kWh} /$ day to anticipate additional loads, the energy is reserved by $30 \%$ of the total energy reserved at $594.0 \mathrm{Wh}$ / day. So that the power generated with an array area of $678.8 \mathrm{~m}^{2}$ and 14 the number of solar panels is $3640 \mathrm{Wp}$.

Keywords : Smart Grid, Solar PV System, Hybrid, PLN

Copyright @ 2019 Universitas Muhammadiyah Jember.

\section{PENDAHULUAN}

Pemanfaatan energi listrik di Gedung G Universitas Muhammadiyah Jember bersumber dari PLN Sebesar 6,6 KVA.Energi listrik yang digunakan untuk mencukupi kebutuhan energi listrik 3 lantai penggunaan energi listrik di Gedung G juga memanfaatkan energi terbarukan berupa PLTS sebagai suplay energi tambahan [1].

Teknologi yang digunakan pada sistem PLTS di Gedung G menggunakan Smart Grid Solar PV System. Smart Grid Solar PV System merupakan pembangkit yang bekerja secara hybrid. Sistem pembangkit hybrid yang digunakan berupa solar PV sistem (photovoltaic) dengan jaringan PLN untuk memenuhi beban [2]. 
Keandalan pemanfaatan energi terbarukan berupa pv solar system sebagai pembangkit energi alternatif dengan System Smart Grid Solar PV-PLN. Supaya memberikan performa pembangkit dengan sistem hybrid menggunakan panel surya (photovoltaic) dengan PLN [3].

Penelitian sebelumnya yang dilakukan oleh Eric Timotius Abit Duka, (2018), Universitas Udayana yang berjudul "Perencanaan Pembangkit Listrik Tenaga Surya Hybrid Pada Area Parkir Gedung Dinas Cipta Karya, Dinas Bina Marga Dan Pengairan Kabupaten Badung” menyatakan bahwa penelitiannya menggunakan PLTS dengan kapasitas 148,272 KW yang memperhitungkan faktor sudut perhitungan sudut kemiringan PV modul sebesar 14,85 . Dengan menggunakan sistem hybrid PLTS dapat mensuplai kebutuhan energi listrik sebesar 30\% yaitu 2,310 MWh [4]. Untuk penelitian sebelumnya yang dilakukan Muhammad Naim, (2017), Akademi Teknik Sorowako, dalam jurnal penelitian berjudul "Rancangan Sistem Kelistrikan PLTS Off Grid 1000 Watt Di Desa Mahalona Kecamatan Towuti". Menyatakan bahwa penelitiannya untuk merancang sistem kelistrikan PLTS Off Grid dengan kapasitas 1000 Watt di Desa Mahalona Kecamatan Towuti Kabupaten Luwu Timur agar nantinya dapat mengatasi permasalahan kelistrikan yang terjadi di wilayah itu [5].

Oleh karena itu tugas akhir ini mengangkat tentang "Studi Implementasi Smart Grid Solar PV System Di Gedung G Universitas Muhammdiyah Jember" yang bekerja secara hybrid dengan jaringan PLN. Dalam penelitian ini dilakukan kajian investasi pada perencanaan solar PV sistem agar mengetahui keuntungan nilai ekonomis pada masa depan.

\section{KAJIAN PUSTAKA}

Penelitian sebelumnya [4] menyatakan bahwa menghitung kebutuhan daya listrik di area parkir gedung Dinas Cipta Karya menghitung kebutuhan modul surya dan kapitas besaran daya inverter, untuk mengoptimalkan pembangkit magnitude sudut kemiringan dan lokasi modul surya menjadi penting. Besarnya daya yang dibangkitkan sebesar 148,272 kWp, dengan jumlah panel sebanyak 985 panel dibagi menjadi 4 string dengan masing-masing berisikan 247 panel yang disusun secara seri paralel.

Penelitian sebelumnya [5] menyatakan bahwa kelistrikan pada sistem Pembangkit Listrik Tenaga Surya Off Grid 1000 Watt di desa Maholona Kecamatan Towuti yang disusun dengan jumlah panel photovoltaicberjumlah 4 buah dengan daya sebesar $260 \mathrm{Wp}$.

Tugas akhir ini mengangkat tentang studi implementsi smart grid solar pv system yang bekerja secara hybrid dengan jaringan PLN untuk memenuhi beban.

\subsection{Pembangkit Listrik Tenaga Surya}

Pembangkit Listrik Tenaga Surya merupakan pembangkit listrik yang memanfaatkan sinar matahari

yang kemudian diubah menjadi energi listrik dengan bantuan sel surya. [6]

2.2. Kapasitas Komponen PLTS

Persamaan menghitung area array PLTS di bawah ini [4].

$$
\text { PV Area PLTS }=\frac{E L}{\text { Gav } \times n P V \times T C F \times \text { nOut }}
$$

Keterangan :

$\mathrm{E}_{\mathrm{L}} \quad$ : Pemakaian energi listrik per hari $(\mathrm{kWh} / \mathrm{hari})$.

Gav : Rata-rata Insolasi harian matahari $\left(\mathrm{kWh} / \mathrm{m}^{2} / \mathrm{hari}\right)$.

Пpv : Efisiensi pada panel surya.

TCF : Temperature pada panel surya/ Temperature correction factor.

$\eta$ out : Efisiensi pada inverter.

Persamaan menghitung daya yang akan dibangkitkan oleh PLTS pada persamaan dibawah ini :

Daya Watt Peak $=$ Area array $x$ PSI $x \eta p v$

Keterangan :

PSI : Peak Solar Insolation

$\eta p v$ : Efisiensi solar cell

Persamaan menghitung daya dibangkitkan dengan persamaan sebagai berikut :

$$
\text { Jumlah Pada Panel Surya }=\frac{P(\text { Watt Peak })}{p m p p}
$$

Keterangan :

$P$ watt peak : Daya dibangkitkan panel surya

PMPP : Daya keluaran maksimum solar cell 


\subsection{Orientasi PV Modul}

Persamaan untuk mengetahui ketinggian maksimum (dalam derajat) ketika matahari mencapai langit $(\alpha)$ [4] dirumuskan sebagai berikut:

$$
\alpha=90^{\circ}-\text { lat }+\delta
$$

Keterangan :

Lat : garis lintang (latitude) PV modul

$\delta$ : deklinasi sudut matahari $[23,45 \delta]$

$\beta=90^{\circ}-\alpha$

\subsection{Faktor Daya}

Cosphi atau faktor daya nilai perbandingan besarnya daya aktif dengan daya semu.

$>$ Cosphi $=\frac{\text { Daya Aktif }}{\text { Daya Semu }}$

$>$ DayaSemu $=$ V $x I x \sqrt{3}$

Jika nilai daya semu dan daya aktuf, nilai cosphinya mendekati 0,1 hal ini dianggap handal pada faktor daya (cosphi).

\subsection{Teknologi Smart Grid}

Teknologi Smart Grid adalah sistem tenaga yang menggunakan teknologi sistem digital untuk memonitoring energi listrik dari sumber pembangkit ke jaringan PLN untuk memenuhi kebutuhan beban listrik yang dihasilkan setiap hari.

\subsection{Panel Solar Cell}

merupakan media menangkap energi cahaya matahari untuk diubah menjadi energi listrik.

2.7. Baterai Opzv 2V 300 Ah

Merupakan Battery Maintance Free dengan tegangan DC 2 Volt dengan arus 300 Ampere hour.

2.8. IMEON Smart Hybrid Inverter

Berfungsi sebagai pengubah arus DC menjadi AC, akan tetapi sistem ini mempunyai kelebihan yaitu ketika ada kelebihan beban yang dihasilkan panel surya maka inverter ini mengirim ke baterai untuk disimpan. Jika aterai penuh maka beban akan langsung dikirim ke jaringan PLN.

2.9. MCB

Merupakan pemutus rangkaian arus listrik secara otomatis dan melindungi rangkaian arus listrik dari beban arus berlebihan.

2.10.Sistem Pengaman Arrester

Sebuah alat yang berfungsi memberikan perlindungan pada instalasi listrik agar tidak terjadi kerusakan atau terbakar.

\section{METODE PENELITIAN}

\subsection{Studi Literatur}

Dilakukan dengan mempelajari literatur yang mengandung dalam penyusunan skripsi ini, antara ini mempelajari tentang dasar-dasar Pembangkit Listrik Tenaga Surya dan Smart Grid Solar PV Sistem.

\subsection{Diagram Blok Smart Grid Solar PV System}

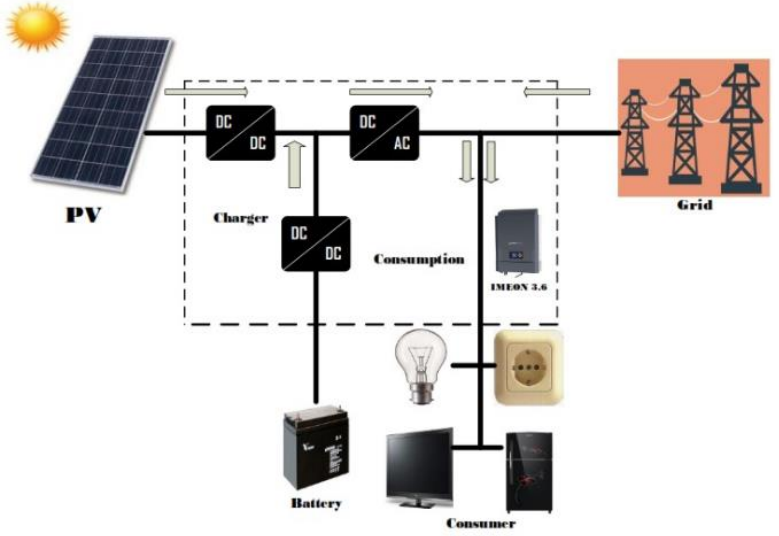

Gambar 1. Diagram Blok Smart Grid Solar PV System 


\subsection{Pengumpulan Data Penelitian}

Metode pengumpulan data penelitian ini menggunakan pengumpulan data dari inverter IMEON 3.6 Smart Grid pada Gedung G Universitas Muhammadiyah Jember meliputi arus (I), tegangan (V), temperatur udara $\left({ }^{\circ} \mathrm{C}\right)$, daya panel surya $(\mathrm{Wp})$. Mengumpulan data terhadap sudut kemiringan modul surya tujuannya untuk mengetahui nilai daya pada keluaran maksimal. Metode pengumpulan dalam penelitian ini dengan mengumpulkan data berupa daya panel surya dengan menggunakan aplikasi perangkat lunak IMEON MANAGER dengan waktu pengambilan data dilakukan selama 4 minggu selama 8 jam per hari dalam rentang waktu 10 menit. Metode pengumpulan data digambarkan melalui diagram alir (flowchart) berikut:

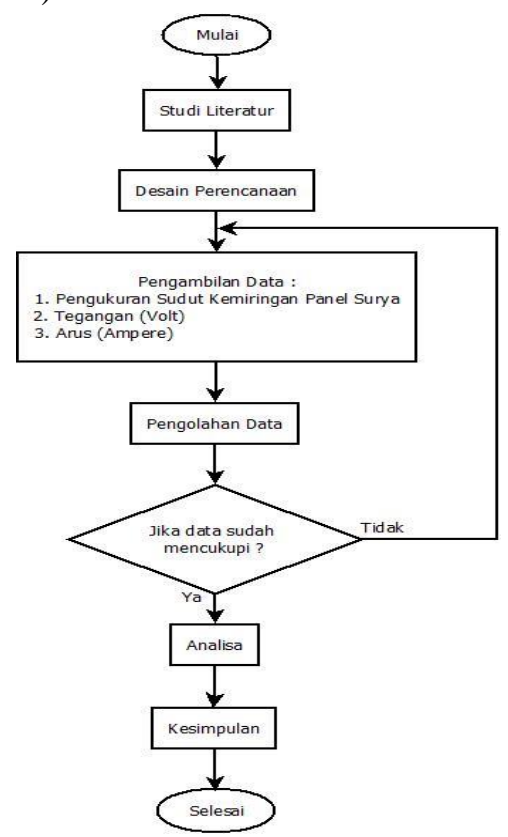

Gambar 2. Diagram Alir Penelitian

\subsection{Prosedur Analisa Data}

Analisa data Smart Grid Solar PV System di Gedung G Universitas Muhammadiyah Jember digambarkan melalui diagram alir (flowchart) berikut:

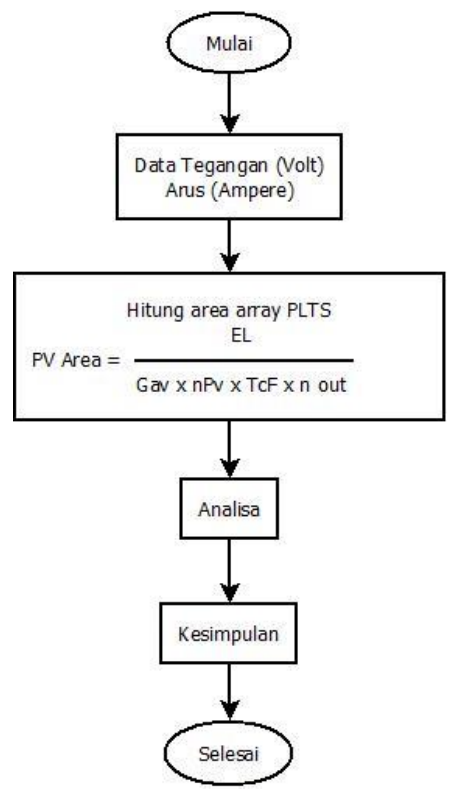

Gambar 3. Flowchart Analisa 


\section{a. Mengumpulkan Data dan Mengolah Data}

Mengumpulkan data dari Gedung G yang merupakan data harian dari sistem Smart Grid Solar $P V$, kemudian mengolahan data yang diperlukan untuk mengetahui daya yang dibangkitkan.

\section{b. Menentukan Area Array PV}

Persamaan menghitung area array untuk mengetahui luas PLTS dapat dicari melauli rumus (2).

\section{c. Perhitungan Daya Yang Dibangkitkan}

Setelah didapat persamaan area array PLTS, selanjutnya adalah perhitungan daya yang dibangkitkan, dengan menggunakan persamaan (3).

\section{HASIL ANALISA DAN PEMBAHASAN}

\subsection{Profil Gedung G}

Penelitian dilakukan pada salah satu gedung di kampus Universitas Muhammadiyah Jember, yaitu gedung $\mathrm{G}$ yang terletak di Jl. Karimata no 49 Jember. Gedung $\mathrm{G}$ terdiri dari 3 lantai memiliki pembangkit listrik tenaga surya menggunakan sistem smart-grid PV solar system dengan inverter IMEON 3.6.

\subsection{Energi Listrik yang Akan Disuplai dari PLTS}

Jika Pembangkit Listrik Tenaga Surya untuk mensuplai energi listrik 30\% dari hasil pemakaian listrik per hari, maka untuk menghitung energi listrik sebagai berikut:

$$
\begin{aligned}
\text { El } & =30 \% \times \text { Rata-rata Pemakaian energi listrik pada Gedung G } \\
& =30 \% \times 1980 \mathrm{Wh} \\
& =594,0 \mathrm{Wh}
\end{aligned}
$$

\subsection{Menghitung Efisiensi Panel Surya}

Daya maksimum keluaran panel (Pmpp) sebesar $260 \mathrm{Wp}$ per panel, menghitung efisiensi pada panel surya menggunakan persamaan dibawah ini:

$$
\begin{aligned}
\eta p v & =\frac{P m p p}{P S I X A} \times 100 \% \\
& =\frac{260 \mathrm{Wp}}{1000 \frac{\mathrm{W}}{\mathrm{m} 2} \times 1,3} \times 100 \% \\
& =20 \%
\end{aligned}
$$

\subsection{Menghitung Area Array (PV Area)}

Dari pemakaian Energi Listrik perhari (EL) pada Gedung G yang disuplai PLTS 594,0 Wh. Nilai insolasi matahari (Gav) di indonesia 4,8 kWh (Hamdi, 2014). Efisiensi Panel Surya ( $\eta \rho v) 260$ Wp sebesar $20 \%$ berdasarkan dari acuan panel surya..

Setiap kenaikan temperatur $1^{\circ} \mathrm{C}$ dari temperatur standartnya panel surya, maka akan daya yang dihasilkan panel surya akan berkurang sekitar $0,5 \%$ (Foster dkk, 2010). Temperatur paling maksimum pada wilayah Jember $32,4^{\circ} \mathrm{C}$ dengan temperatur standartnya $25^{\circ} \mathrm{C}$ sebesar $7,4^{\circ} \mathrm{C}$ pada panel surya. Dapat dihitung dengan rumus :

$$
\begin{aligned}
\mathrm{P} \text { saat } \mathrm{t}=32,4^{\circ} \mathrm{C} & =0,5 \% /{ }^{\circ} \mathrm{C} \times \mathrm{Pmpp} \times \text { naiknya temperatur }\left({ }^{\circ} \mathrm{C}\right) \\
& =0,5 \% /{ }^{\circ} \mathrm{C} \times 260 \mathrm{~W} \times 7,4{ }^{\circ} \mathrm{C} \\
& =9,62 \mathrm{Watt}
\end{aligned}
$$

PMPP ( Daya maksimum keluaran panel surya) saat naik $t^{\circ} \mathrm{C}=\mathrm{PMPP}-\mathrm{P}$ saat $\mathrm{t}$ naik ${ }^{\circ} \mathrm{C}$

$$
\begin{aligned}
& =260 \mathrm{~W}-9,62 \mathrm{~W} \\
& =250,38 \mathrm{Watt}
\end{aligned}
$$

Untuk menghitung TFC pada temperatur naik menjadi $32,4^{\circ} \mathrm{C}$ dengan rumus sebagai berikut:

$$
\begin{aligned}
\mathrm{TFC} & =\frac{\text { PMPP saat } \mathrm{t} \text { naik } \mathrm{t}^{\circ} \mathrm{C}}{P M P P} \\
& =\frac{250,38 \mathrm{~W}}{260 \mathrm{w}} \\
& =0,96
\end{aligned}
$$


Selanjutnya dapat menghitung berdasarkan persamaan (2)

$$
\begin{aligned}
\text { PV Area } & =\frac{E L}{G a v \times n P V \times T C F \times n O u t} \\
& =\frac{594,0 \mathrm{~W}}{4,8 \frac{k W h}{m 2} \times 20 \% \times 0,96 \times 0,95} \\
& =678,8 \mathrm{~m}^{2}
\end{aligned}
$$

\subsection{Daya PLTS yang Dibangkitkan}

Dapat dihitung dengan rumus di bawah ini :

$$
\begin{aligned}
\boldsymbol{P}_{\text {wattpeak }} & =\text { Area array } \times \text { PSI } \times \eta \rho v \\
& =678,8 \times 1000 \times 0,20 \\
& =135,760 \text { Wattpeak }
\end{aligned}
$$

Jika PV area 678,8 $\mathrm{m}^{2}$ maka akan menghasilkan daya sebesar 135,760 Wattpeak, namun pada Gedung G Universitas Muhammadiyah Jember hanya memasang 14 panel surya, dengan luas 1,3 maka daya yang akan dihasilkan sebgai beriku :

$$
\begin{aligned}
\boldsymbol{P}_{\text {wattpeak }} & =(1,3 \mathrm{~m} \times 14 \text { panel }) \times 1000 \mathrm{~W} / \mathrm{m}^{2} \times 0,20 \\
& =3,640 \text { Wattpeak }
\end{aligned}
$$

\subsection{Kapasitas Baterai}

Pada PLTS di gedung G Universitas Muhammadiyah Jember terdapat baterai yang berjumlah 24 dengan susunan seri. Dilihat dari spesifikasi baterai ini mempunyai tegangan dan arus sebesar $2 \mathrm{~V}$ dan $300 \mathrm{Ah}$. Jadi untuk mendapatkan tegangan sebsar $48 \mathrm{~V}$ maka 24 baterai diseri kemudian diparelelkan dengan lainnya. Menggunakan rumus daya sebagai berikut:

$$
\begin{aligned}
\text { Daya per jam } & =\mathrm{I}(\text { Arus Ah x V (Tegangan baterai) } \\
& =300 \mathrm{Ah} \times 2 \mathrm{~V} \\
& =600 \mathrm{Wh}
\end{aligned}
$$

Maka kapasitas baterai pada gedung $\mathrm{G}$ adalah daya per jam dikali dengan jumlah baterai yaitu 600 Wh $\times 24$ baterai $=14.400 \mathrm{Wh}$.

\subsection{Faktor Daya}

Sistem Pembangkit Listrik Tenaga Surya dikatakan handal terhadap Faktor Daya jika nilai Daya Semu adalah sama dengan Daya Aktif, maka nilai Cosphi (Faktor dayanya adalah mendekati 0,1). Untuk menentukan nilai Cosphi dapat dihitung menggunakan rumus persamaan 6 dibawah ini :

$$
\text { Cosphi }=\frac{\text { Daya Aktif }}{\text { Daya Semu }}
$$

Daya Aktif di peroleh dari total jumlah daya pada panel surya selama 4 minggu dari Tanggal 8 Februari 2020 sampai dengan Tanggal 7 Maret 2020 dengan total daya sebesar 2771 Watt.

$$
\begin{aligned}
\text { Daya Aktif } & =\text { Daya Panel Surya Selama 4 Minggu } \\
& =751+610+650+760 \\
& =2771 \mathrm{~W}
\end{aligned}
$$

Untuk menentukan Daya Semu menggunakan rumus persamaan 6 dan persamaan 7 dibawah ini:

$$
\begin{aligned}
\text { Daya Semu } & =\mathrm{V} \times \mathrm{I} \times \sqrt{3} \\
& =(751 \times \sqrt{3})+(610 \times \sqrt{3})+(650 \times \sqrt{3})+(760 \times \sqrt{3}) \\
& =4799 \mathrm{VA}
\end{aligned}
$$

$$
\begin{aligned}
\text { Maka nilai Cosphi } & =\frac{\text { Daya Aktif }}{\text { Daya Semu }} \\
& =\frac{2771}{4799}=0,5
\end{aligned}
$$

Jadi sistem keandalan pada pembangkit $p v$ solar smart grid pada gedung G Universitas Muhammadiyah Jember dikatakan handal karena nilai pada Faktor Daya dari Daya Semu sama dengan Daya Aktif, yang nilai Cosphinya sebesar 0,5. Hal ini dianggap handal nilai Faktor Daya Cosphinya $>0,1$. 


\subsection{Prinsip Kerja Sistem Smart Grid Di Gedung G}

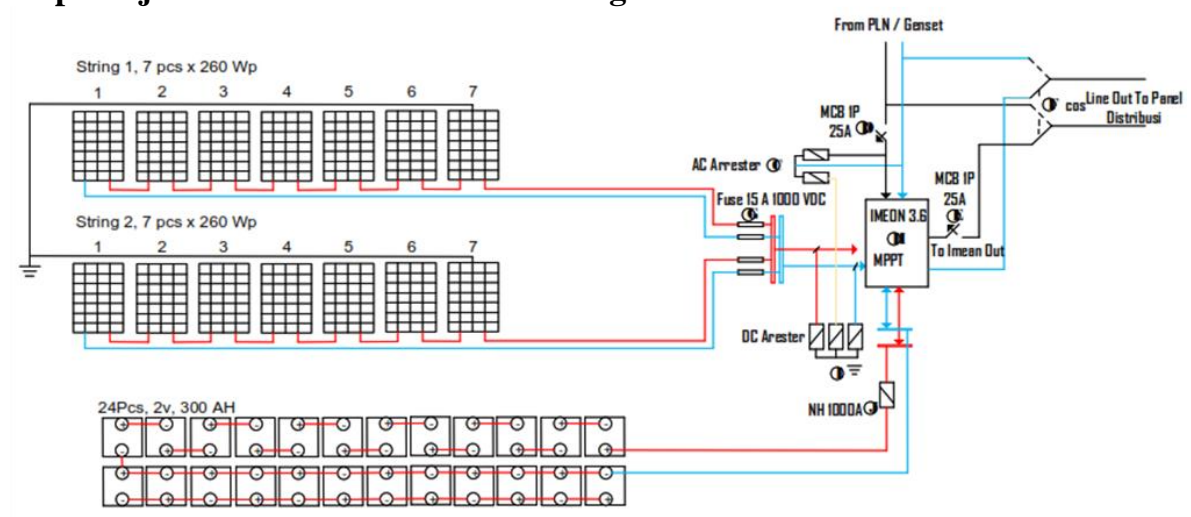

Gambar 5. Desain Smart Grid Solar PV System Gedung G

\subsection{Data Daya Penelitian pada Gedung G}

Tabel 1 berikut menunjukkan daya rata-rata panel surya pada tanggal 8-15 Februari 2020

Tabel 1. Data Daya Rata-rata Panel Surya Per Hari Tanggal 8-15 Februari 2020

\begin{tabular}{cll}
\hline No & \multicolumn{1}{c}{ Waktu } & Daya Panel Surya Per Hari (Wp) \\
\hline 1 & 8 Februari 2020 & 906,3023 \\
2 & 10 Februari 2020 & 965,514 \\
3 & 11 Februari 2020 & 706,6511 \\
4 & 12 Februari 2020 & 598,0233 \\
5 & 13 Februari 2020 & 893,2326 \\
6 & 14 Februari 2020 & 542,8837 \\
7 & 15 Februari 2020 & 699,1163 \\
& Total & 527,723 \\
\hline
\end{tabular}

Berdasarkan Tabel diatas menjelaskan bahwa daya panel surya per hari tanggal 8 februari - 15 februari 2020 dengan daya mengalami kenaikan pada tanggal 10 februari sebesar 965,514 Wp, kemudian mengalami penurunan sebesar 542,8837 Wp pada tanggal 14 Februari 2020. Hal itu disebabkan kondisi cuaca yang mendung dan hujan deras.

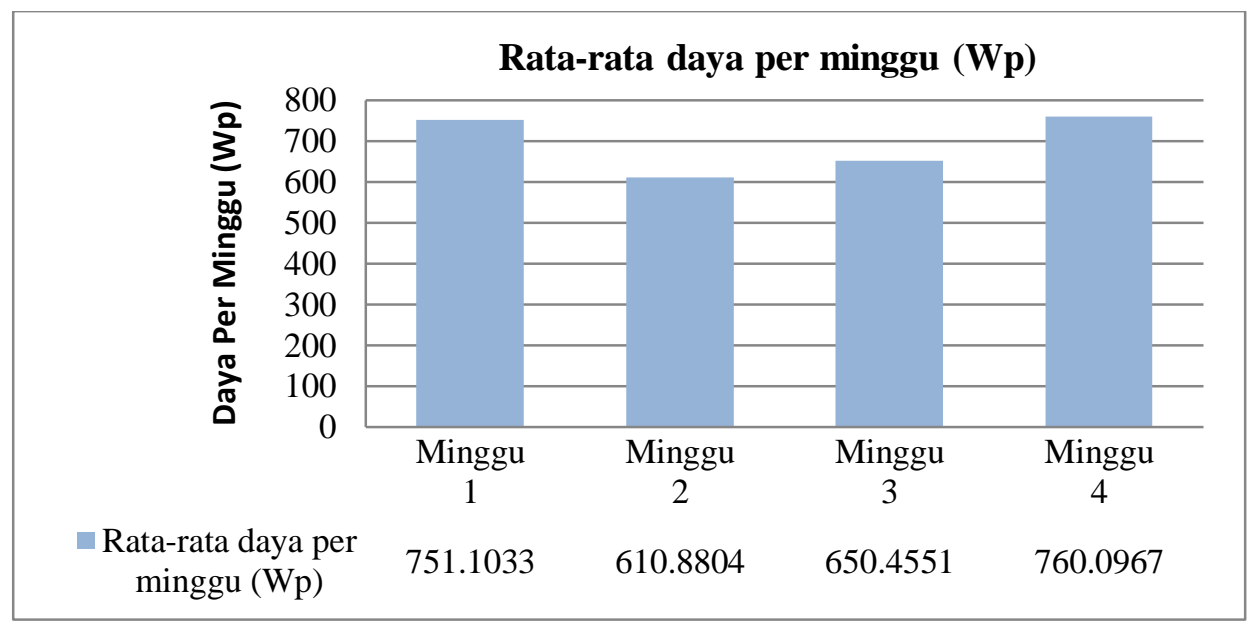

Gambar 6. Grafik Daya Panel Surya Selama 4 Minggu

Pada gambar 4 menunjukan daya panel surya selama 4 minggu di Gedung G pada tanggal 8 Februari sampai 7 Maret 2020 daya rata-rata mengalami penurunan minggu ke 2 dan minggu ke 3 dengan daya sebesar 610,8804 Wp DAN 650,4551 Wp. Pada minggu ke 4 daya mengalami kenaikan sebesar 760,0967 Wp. Hal itu disebabkan cuaca pada bulan Februari hingga Maret wilayah Jember sering terjadi cuaca mendung dan hujan deras, maka daya yang dihasilkan kurang stabil. 


\section{KESIMPULAN}

Hasil dari penelitian, dapat disimpulkan beberapa hal sebagai berikut :

1. Berdasarkan hasil dari perhitungan, estimasi total kebutuhan energi harian Gedung G Universitas Muhammadiyah Jember sebesar $1980 \mathrm{Wh} /$ hari. Sedangkan untuk mengantisipasi penambahan beban maka energi dicadangkan sebesar $30 \%$ dari total energi yang dicadangkan. Sehingga total estimasi kebutuhan energi listrik pada Gedung G sebesar 594,0 Wh/hari. Sedangkan daya yang dibangkitkan dengan area array $678,8 \mathrm{~m}^{2}$ dengan jumlah 14 panel surya dan luas panel 1,3 $\mathrm{m}^{2}$. Maka daya yang di bangkitkan sebesar $3640 \mathrm{Wp}$. Hasil dari penelitian kebutuhan energi listrik selama 4 Minggu pada Gedung G sebesar 5257 Wp.

2. Dari hasil perhitungan dan penelitian di Gedung G Universitas Muhammadiyah Jember, maka sistem keandalan dilihat dari nilai faktor daya (cosphi) pada daya semu sama dengan daya aktif yang nilai cosphinya mendekati 0,1 . Jadi pada sistem pembangkit pv solar smart grid pada Gedung $\mathrm{G}$ Universitas Muhammadiyah Jember dikatakan handal karena nilai pada faktor daya (cosphi) nya sebesar 0,5. Dari kebutuhan daya yang dihasilkan pada Gedung G sebesar 594,0 Wh/hari dan suplay daya yang disalurkan panel surya per hari sebesar $5257 \mathrm{Wp}$ sangat optimal atau sangat efisien walaupun saat kondisi cuaca pada bulan Februari sampai Maret sering terjadi mendung dan hujan deras. Maka sisa pemakaian daya yang di hasilkan pembangkit sebesar $4663 \mathrm{Wp}$, sisa daya tersebut masih tertampung di sisi baterai oleh karena itu kedepan butuh pemanfaatan. Karena energi yang dibangkitkan berlebih jadi butuh pengembangan pada sisi pemanfaatan untuk pembebanan yang lain.

\section{REFERENSI}

[1] D.P. Putri, S. Koenhardono, dan I.R. Kusuma, "Perencanaan Sistem Pembangkit Listrik Hybrid (Sel Surya dan Diesel Generator) Pada Kapal Tenker,” Jurnal Teknik ITS, vol.5, no.2, pp. B394-B.399, 2016, doi: 10.12962/j23373539.v5i2.19318.

[2] A.I. Ramadhan, E.Diniardi, dan S.H. Mukti, "Analisis Desain Sistem Pembangkit Listrik Tenaga Surya Kapasitas 50 Wp,” Teknik, vol.37, no.2, pp.59-63, 2016, 10.14710/teknik.v37n2.9011.

[3] R.A. Rohmana, G. Nugroho, dan C. Budiono, "Analisa Performa dan Monitoring Solar System (SPS) Pada Pembangkit Listrik Tenaga Surya Di Tuban Jawa Timur,” Jurnal Teknik Pomits, pp.1-8, 2013, doi: 10.1007/s10853-010-4707-x

[4] E.T.A Duka, I.N. Setiawan, dan A.I. Weking, "Perencanaan Pembangkit Listrik Tenaga Surya Hybrid Pada Area Gedung Parkir Dinas Cipta Karya, Dinas Bina Marga DAN Pengairan Kabupaten Badung," E-Journal Spektrum, vol.5, pp.67-73, 2018, doi: 10.24843/SPEKTRUM.2018.v05.i02.p09.

[5] M. Naim, "Rancangan Sistem Kelistrikan PLTS Off Grid 1000 Watt Di Desa Mahalona Kecamatan Towuti," DINAMIKA Jurnal Ilmiah Teknik Mesin, vol.9, no.1, pp.27-32, 2017, doi: 10.33772/djitm.v9i1.3216.

[6] Suriadi dan M. Syukri, "Perencanaan Pembangkit Listrik Tenaga Surya (PLTS) Terpadu Menggunakan Softwere PVSYST Pada Kompleks Perumahan Di Banda Aceh”, vol.9, no.2, pp.77-80, 2010, doi: 10.17529/jre.v9i2.167.

[7] Stevenson, Jr., Wiliam D. 1984. Analisis Sistem Tenaga Listrik. Jakarta : Penerbit Erlangga 


\section{BIOGRAFI PENULIS}

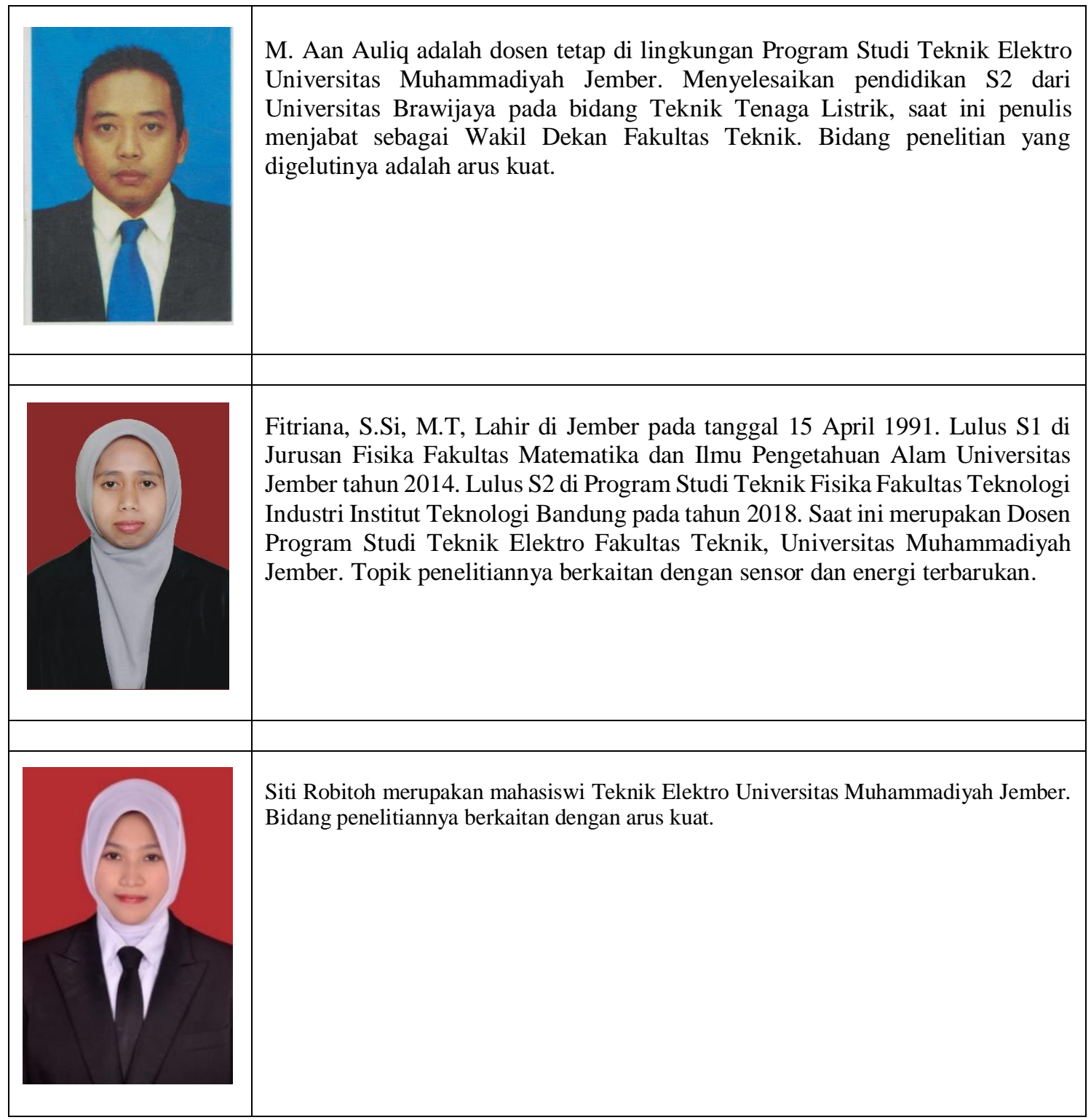

